\title{
3D models related to the publication: Wild versus lab house mice: Effects of age, diet, and genetics on molar geometry and topography.
}

\author{
Sabrina Renaud ${ }^{1 *}$, Caroline Romestaing ${ }^{2}$, Yoland Savriama ${ }^{3}$ \\ ${ }^{1}$ Laboratoire de Biométrie et Biologie Evolutive, UMR 5558 CNRS, Université Claude Bernard Lyon 1, Université de Lyon, Campus de la Doua, 69100 \\ Villeurbanne, France \\ ${ }^{2}$ Laboratoire d'Écologie des Hydrosystèmes Naturels et Anthropisés (LEHNA), ENTPE, Université de Lyon, Université Claude Bernard Lyon 1, UMR \\ 5023 CNRS, F-69622, Villeurbanne, France \\ ${ }^{3}$ Max-Planck Institute for Evolutionary Biology, Plön, Germany \\ *Corresponding author: Sabrina.Renaud@univ-lyon1.fr
}

\begin{abstract}
This contribution contains 3D models of upper molar rows of house mice (Mus musculus domesticus). The erupted parts of the right row and of the first upper molar are presented for specimens belonging to four groups: wild-trapped mice, wild-derived lab offspring, a typical laboratory strain (Swiss) and hybrids between wild-derived and Swiss mice. These models are analyzed in the following publication: Savriama et al 2021: Wild versus lab house mice: Effects of age, diet, and genetics on molar geometry and topography. https://doi.org/10.1111/joa.13529
\end{abstract}

Keywords: dental functional morphology, geometric morphometrics, hybridization, mastication, occlusal relief

Submitted:2021-03-25, published online:2021-08-06. https://doi.org/10.18563/journal.m3.141

\section{INTRODUCTION}

This contribution presents 3D models of molars for 30 specimens of Western European house mouse (Mus musculus domesticus). Four groups of mice were considered: (1) wild-trapped mice $(\mathrm{N}=7)$, captured in a horse stable near Lyon (Balan, France); (2) laboratory offspring bred from mice from the same locality $(\mathrm{N}=14)$; (3) Swiss mice, documenting one of the most common outbred laboratory strain $(\mathrm{N}=5) ;(4)$ hybrids $(\mathrm{N}=4)$ derived from crosses between lab offspring of wild mice and Swiss mice (Table 1). For each specimen, three models were extracted from the right upper jaw: the upper molar row with the three teeth in connection (UMR), the first molar only (UM1), and a truncated template of the first molar mimicking advanced wear (UM1tr). The root part was discarded and only the erupted part of the teeth was considered. The only exception was a young mouse at weaning. Its third molar was on the course of eruption, preventing the extraction of a continuous surface for the molar row. A geometric morphometric study was performed on these three sets of molar descriptors, using a generalized Procrustes superimposition procedure. The upper molar row was described by a set of 2186 sliding semi-landmarks, the first molar by 2199 semi-landmarks, and the truncated UM1 by 2293 semi-landmarks (Savriama et al. XXXX). This study showed that non-heritable variation due to differences in mastication and diet between wild and lab mice was of primary importance, especially when considering the whole molar row (Fig. 1). Some wild-trapped mice displayed extremely advanced wear compared to all lab animals. All wild-trapped mice, even young specimens, further displayed molar rows in which the second and especially the third molar were shifted away from the alignment of the first molar cusps. This was interpreted as related to mechanical loadings during mastication (Renaud and Ledevin 2017). The different wear trajectories along age observed between wild and lab animals indicated increased masticatory demand in the wild. These non-heritable sources of variance override the difference between wild-derived mice and the Swiss strain, corresponding to localized changes in the size and position of some cusps. Hybrids display a transgressive morphology suggestive of epistasis involved in the highly polygenic molar morphology (Pallares et al. 2017). The truncated model of the first molar, by discarding the effect of wear, allowed to focus on such heritable differences.

\section{METHODS}

The specimens were scanned at a cubic voxel resolution of 12 $\mu \mathrm{m}$ (except for SW01 and SW02 scanned at $13.5 \mu \mathrm{m}$ ) using a Phoenix Nanotom $S$ microtomograph $(\mu C T)$ on the AniRAImmOs platform of the SFR Biosciences (UMS 3444, ENS Lyon). The scanning parameters were as follows: $100 \mathrm{kV}, 70 \mu \mathrm{A}$, 3000 projections at $360^{\circ}$ with $\mathrm{Cu}$ filter. For each mouse, the right upper molar row was delimited using Avizo (v. 9.1-Visualization Science Group, FEI Company). In most cases, an automatic threshold was sufficient to isolate the molar row from the surrounding bone and generate a surface including the roots; in a few cases, connections with the bone had to be manually delimited. A template isolating the erupted part of the molar row was designed for one specimen (Balan Lab 86). This template was modified to include the first upper molar only. Finally, a truncated template of the first upper molar was designed, with the top of the cusps cut to mimic an advanced degree of wear, in order to mitigate the effect of tooth abrasion on the morphological signal (Ledevin et al. 2016). These templates were used 


\begin{tabular}{|c|c|c|c|c|c|c|c|}
\hline Ind. & Population & Weight & Sex & Age & UMR & UM1 & UM1tr \\
\hline BW_03 & Balan Wild & 12.0 & & & $X$ & $\mathrm{X}$ & $\mathrm{X}$ \\
\hline BW_04 & Balan Wild & 21.1 .0 & $\mathrm{~F}$ & & $\mathrm{X}$ & $X$ & $\mathrm{X}$ \\
\hline BW_06 & Balan Wild & 17.1 & & & $\mathrm{X}$ & $\mathrm{X}$ & $\mathrm{X}$ \\
\hline BW_07 & Balan Wild & 11.3 & & & $\mathrm{X}$ & $X$ & $\mathrm{X}$ \\
\hline BW_08 & Balan Wild & 17.3 & $\mathrm{~F}$ & & $\mathrm{X}$ & $X$ & $\mathrm{X}$ \\
\hline BW_11 & Balan Wild & 10.9 & & & X & $\mathrm{X}$ & $\mathrm{X}$ \\
\hline BW_12 & Balan Wild & 11.1 & & & $\mathrm{X}$ & $X$ & $X$ \\
\hline Blab_035 & Balan Lab & 14.7 & $\mathrm{~F}$ & 98 & $\mathrm{X}$ & $X$ & $\mathrm{X}$ \\
\hline Blab_046 & Balan Lab & 16.0 & $\mathrm{~F}$ & 85 & $\mathrm{X}$ & $X$ & $\mathrm{X}$ \\
\hline Blab_054 & Balan Lab & 17.4 & $\mathrm{~F}$ & 73 & $\mathrm{X}$ & $X$ & $\mathrm{X}$ \\
\hline Blab_056 & Balan Lab & 16.3 & $\mathrm{~F}$ & 74 & $X$ & $X$ & $\mathrm{X}$ \\
\hline Blab_082 & Balan Lab & 25.8 & $\mathrm{M}$ & 118 & $\mathrm{X}$ & $X$ & $\mathrm{X}$ \\
\hline Blab_086 & Balan Lab & 24.0 & M & 108 & $\mathrm{X}$ & $X$ & $\mathrm{X}$ \\
\hline Blab_092 & Balan Lab & 21.0 & M & 112 & $\mathrm{X}$ & $\mathrm{X}$ & $\mathrm{X}$ \\
\hline Blab_319 & Balan Lab & 18.5 & $\mathrm{~F}$ & 68 & $X$ & $X$ & $\mathrm{X}$ \\
\hline Blab_325 & Balan Lab & 22.5 & $\mathrm{M}$ & 74 & $\mathrm{X}$ & $X$ & $\mathrm{X}$ \\
\hline Blab_329 & Balan Lab & 21.0 & M & 74 & $X$ & $X$ & $\mathrm{X}$ \\
\hline Blab_330 & Balan Lab & 23.6 & M & 74 & $\mathrm{X}$ & $\mathrm{X}$ & $\mathrm{X}$ \\
\hline Blab_F2a & Balan Lab & & $\mathrm{F}$ & 63 & $\mathrm{X}$ & $X$ & $\mathrm{X}$ \\
\hline Blab_F2b & Balan Lab & 16.1 & $\mathrm{~F}$ & 66 & $\mathrm{X}$ & $\mathrm{X}$ & $X$ \\
\hline Blab_BB3w & Balan Lab & 9.0 & & 21 & & $X$ & $\mathrm{X}$ \\
\hline hyb_BS01 & Hybrids & & $\mathrm{F}$ & 96 & $\mathrm{X}$ & $X$ & $X$ \\
\hline hyb_BS02 & Hybrids & & $\mathrm{F}$ & 96 & $\mathrm{X}$ & $X$ & $X$ \\
\hline hyb_SB01 & Hybrids & & $\mathrm{F}$ & 95 & $\mathrm{X}$ & $X$ & $\mathrm{X}$ \\
\hline hyb_SB02 & Hybrids & & $\mathrm{F}$ & 95 & $X$ & $X$ & $\mathrm{X}$ \\
\hline SW_001 & Swiss & 44.3 & M & 87 & $\mathrm{X}$ & $\mathrm{X}$ & $\mathrm{X}$ \\
\hline SW_002 & Swiss & 39.9 & $\mathrm{M}$ & 118 & $\mathrm{X}$ & $X$ & $\mathrm{X}$ \\
\hline SW_005 & Swiss & 41.6 & M & 99 & $\mathrm{X}$ & $\mathrm{X}$ & $\mathrm{X}$ \\
\hline SW_0ter & Swiss & 34.4 & M & 64 & $X$ & $X$ & $\mathrm{X}$ \\
\hline SW_343 & Swiss & 37.5 & M & 74 & $X$ & $\mathrm{X}$ & $\mathrm{X}$ \\
\hline
\end{tabular}

Table 1. Label, population, weight, sex and age of the specimens. Specimens are stored at the LBBE (University Lyon 1, France). UMR, UM1, UM1tr: indication of the corresponding surface in the dataset.

to extract a similar surface from the other tooth rows, leading to three series of surfaces: upper molar row (UMR), first upper molar (UM1) and truncated first upper molar (UM1tr). The 3D surfaces are provided in .ply format, and can therefore be opened with a wide range of freeware.

\section{ACKNOWLEDGEMENTS}

We thank the horse stable Les Peupliers (Balan) for their authorization and support during the trapping, as well as Angéline Clair, Laetitia Averty, and Julie Ullman, who managed the acclimation and breeding of the mice. This work was supported by the Fédération de Recherche BioEnviS - FR3728 of University Claude Bernard Lyon 1.

\section{BIBLIOGRAPHY}

Ledevin, R., Chevret, P., Ganem, G., Britton-Davidian, J., Hardouin, E. A., Chapuis, J.-L., et al. (2016). Phylogeny and adaptation shape the teeth of insular mice. Proceedings of the Royal Society of London, Biological Sciences (serie B), 283, 20152820, https://doi.org/10.1098/rspb.2015.2820
Pallares, L. F., Ledevin, R., Pantalacci, S., Turner, L. M., Steingrimsson, E., \& Renaud, S. (2017). Genomic regions controlling shape variation in the first upper molar of the house mouse. eLife, 6, e29510, https://doi.org/10.7554/eLife.29510

Renaud, S., \& Ledevin, R. (2017). Impact of wear and diet on molar row geometry and topography in the house mouse. Archives of Oral Biology, 81, 31-40, https://doi.org/10.1016/j. archoralbio.2017.04.028

Savriama, Y., Romestaing, C., Clair, A., Averty, L., Ulmann, J., Ledevin, R., \& Renaud, S. (2021). Wild versus lab house mice: Effects of age, diet, and genetics on molar geometry and topography. Journal of Anatomy. https://doi.org/10.1111/joa.1 3529 


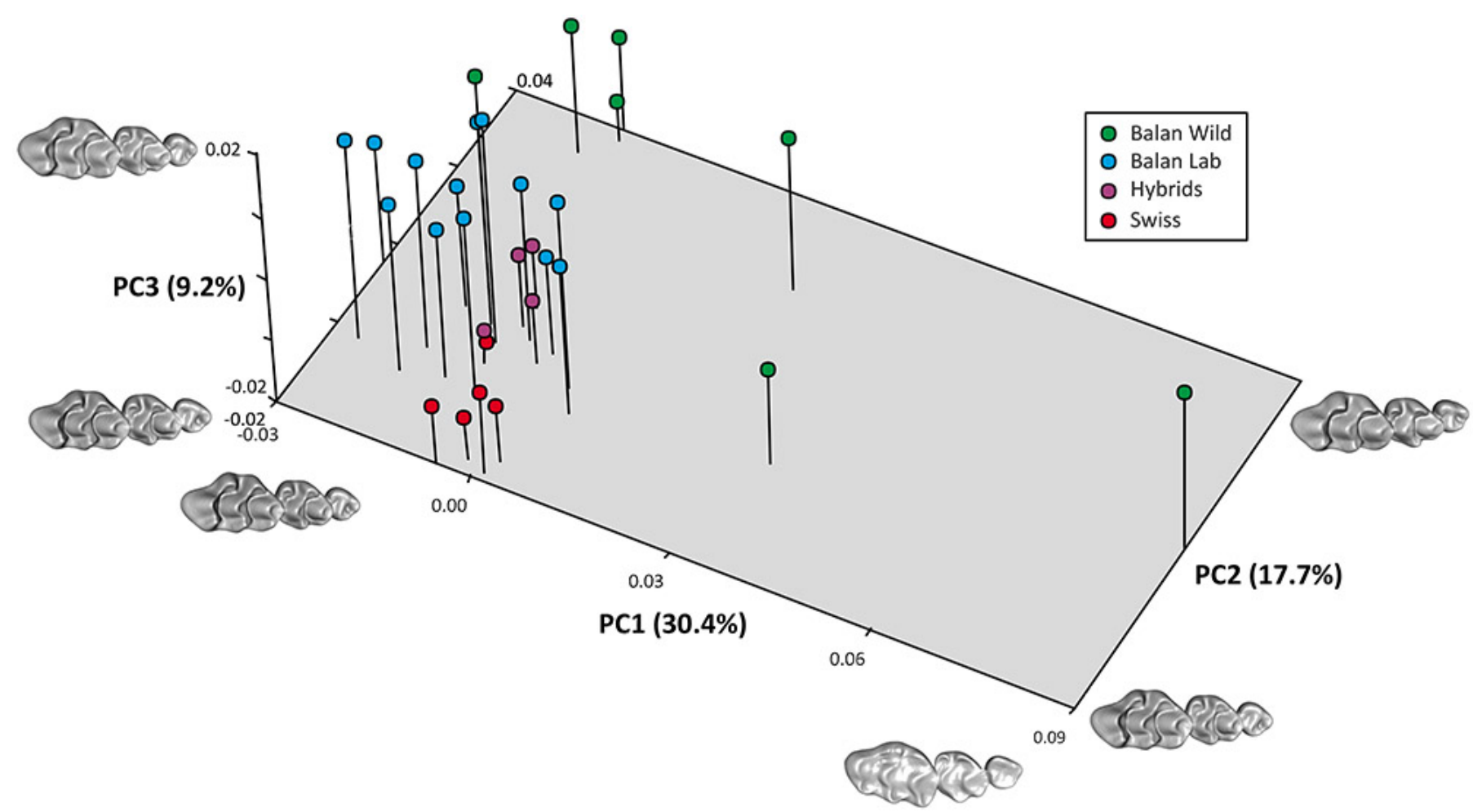

Figure 1. Shape differentiation of the upper molar row between wild mice, their lab offspring, Swiss strain and hybrids. First, second and third axes of a PCA on the aligned coordinates are represented, with shapes corresponding to extreme scores along the axes. 